\title{
Infection prevention guidelines and considerations for paediatric risk groups when reopening primary schools during COVID-19 pandemic, Norway, April 2020
}

Tone Bjordal Johansen ${ }^{1,2}$, Elisabeth Astrup ${ }^{1}$, Solveig Jore ${ }^{1}$, Hege Nilssen ${ }^{3}$, Bente Barton Dahlberg ${ }^{3}$, Claus Klingenberg ${ }^{4,5}$, Are Stuwitz Berg ${ }^{1}$, Margrethe Greve-Isdahl ${ }^{1}$

1. The Norwegian Institute of Public Health, Oslo, Norway

2. European Public Health Microbiology Training Programme (EUPHEM), European Centre for Disease Prevention and Control (ECDC), Stockholm, Sweden

3. The Norwegian Directorate for Education and Training, Oslo, Norway

4. Paediatric Research Group, Faculty of Health Sciences, University of Troms $\varnothing$-Arctic University of Norway, Troms $\varnothing$, Norway

5. Department of Paediatrics and Adolescence Medicine, University Hospital of North Norway, Troms $\emptyset$, Norway

Correspondence: Tone Bjordal Johansen (tone.johansen@fhi.no)

In response to the coronavirus disease (COVID-19) pandemic, most countries implemented school closures. In Norway, schools closed on 13 March 2020. The evidence of effect on disease transmission was limited, while negative consequences were evident. Before reopening, risk-assessment for paediatric risk groups was performed, concluding that most children can attend school with few conditions requiring preventative homeschooling. We here present infection prevention and control guidelines for primary schools and recommendations for paediatric risk groups.

In response to the coronavirus disease (COVID-19) pandemic, 185 countries had implemented regional or national school closures by 1 April 2020, affecting $89.4 \%$ of the world's children [1]. We here present guidelines developed for the reopening of primary schools in Norway.

\section{COVID-19 epidemic in Norway}

Norway reported its first COVID-19 case on 26 February 2020. Quarantine and isolation were implemented for travellers coming to Norway from affected areas and for confirmed COVID-19 cases on 7 March, effective retroactively from 22 February. On 12 March, the government announced a series of restrictive infection control measures after a rapid increase in cases and evidence of community transmission (Figure). These included border control and a travel ban; closure of daycares, schools, universities and businesses; and a ban on mass gatherings. A strict lockdown was never imposed, but the general rule was to work from home and avoid public transportation. The population mobility dropped dramatically overnight $[2,3]$.
On 24 March 2020, the Norwegian Institute of Public Health (NIPH) presented a risk assessment with multiple scenarios based on different target effective reproduction numbers $\left(R_{\text {eff }}\right)$. The government decided to follow an aggressive strategy aiming for a $R$ eff $^{<1}$ to avoid overwhelming the healthcare system [2]. The implemented measures proved effective, reaching a $R_{\text {eff }}$ of 0.67 by 7 April [4]. However, because of the social and economic consequences, the need to reopen parts of society became urgent.

\section{School closures and transmission of SARS-CoV-2}

Evidence for the effect of school closures on disease transmission is mainly based on influenza studies. School closures are most likely to be efficient if the virus has a low reproduction number $(R<2)$ and if attack rates are higher in children than in adults [5]. However, although estimates vary widely, the $\mathrm{R}_{0}$ of severe acute respiratory syndrome coronavirus 2 (SARS-CoV-2) is estimated to be between 2.2 and 3.6 [6-8]. Children are drivers for influenza transmission, but seem to contribute less to the spread of COVID-19 [5,9]. Countries where schools and daycare institutions remained open have not reported outbreaks among children, only sporadic cases [10].

In Norway, as well as globally, the proportion of children with COVID-19 has been low [9,11]. By 11 May, 8,135 COVID-19 cases were reported to the Norwegian Surveillance System for Communicable Diseases (MSIS), of which 72 (0.9\%) were aged o to 5 years, 162 (2.0\%) were aged 6 to 13 years, $341(4.2 \%)$ were aged 14 to 19 years and 7,560 (93.0\%) were over 19 years (Figure). 
Number of confirmed COVID-19 cases reported to the Norwegian Surveillance System for Communicable Diseases (MSIS), Norway, 21 February-11 May $2020(\mathrm{n}=8,135)$

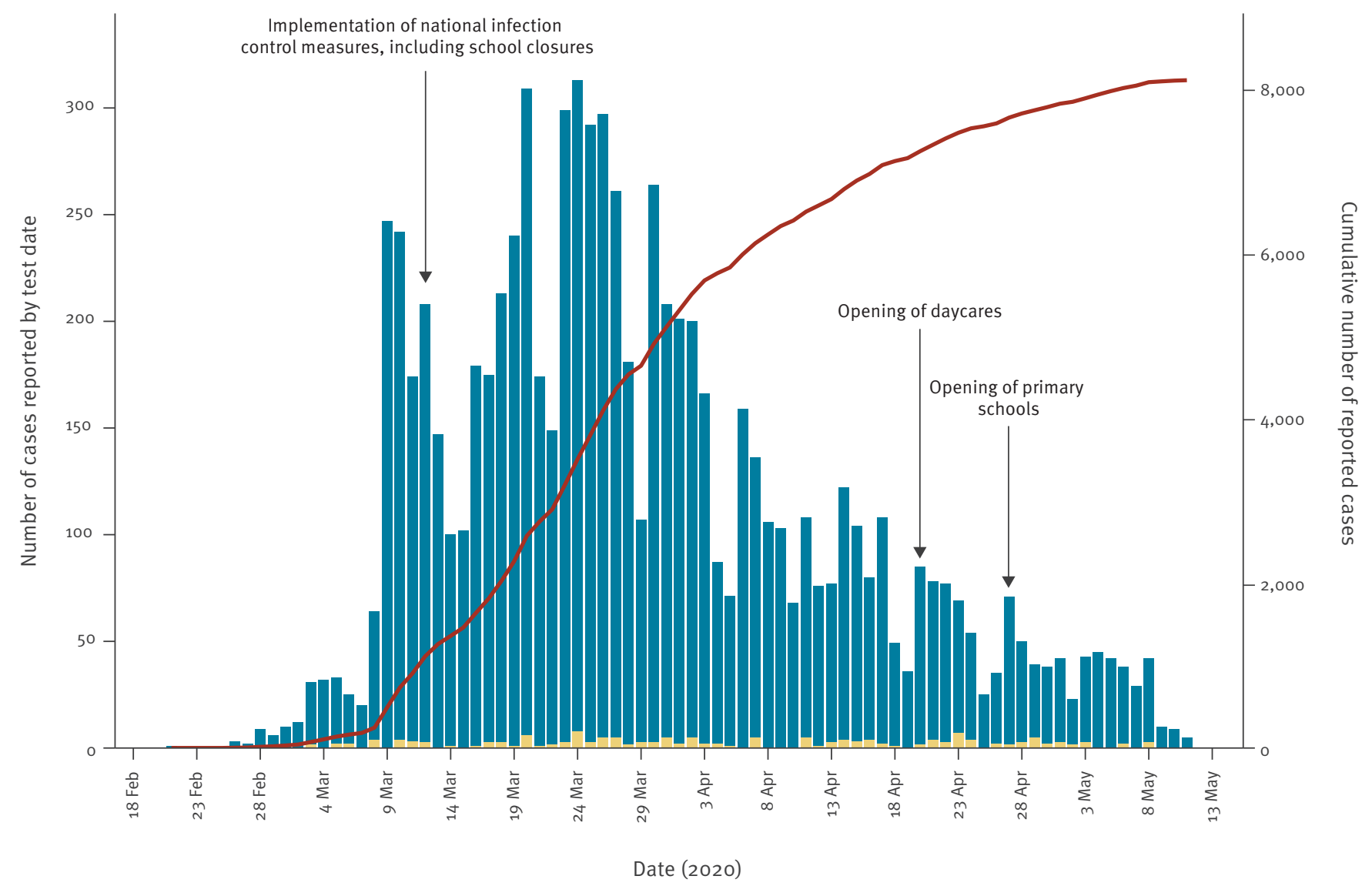

6-13 years of age $(n=162) \quad \leq 5$ and $\geq 14$ years of age $(n=7,973) \quad-$ Cumulative number of reported cases

The figure illustrates number of confirmed cases reported according to test date among children 6 to 13 years of age and in the population $\leq 5$ and $\geq 14$ years of age, as well as the cumulative number of reported cases. Dates for implementation of infection control measures, including school closures, are illustrated.

Based on the current evidence and children's fundamental rights [12], the government announced a gradual reopening of the society, starting with children's daycares 20 April, primary school grades 1 to 4 on 27 April and higher grades (5 to 13) on 11 May. In order to help schools reopen in a secure manner, the NIPH and the Norwegian Directorate for Education and Training (NDET) were asked to develop specific infection prevention and control (IPC) guidelines. Our guidelines consist of practical IPC advice and assessment of paediatric conditions with risk of severe COVID-19 in terms of school attendance.

\section{Guidelines for infection prevention in primary schools}

The IPC guidelines were developed for primary schools (grade $1-7$, children 6-13 years of age) to apply during the COVID-19 epidemic, and were nationally regulated by law [13]. However, local adaptation was encouraged with assistance of local health authorities.
We reviewed the recommendations from the United Nations Children's Fund (UNICEF), the World Health Organization (WHO) and the International Federation of the Red Cross (IFRC) [14], as well as guidelines developed by public health authorities in Canada, Denmark, the United Kingdom and United States available online [15-18]. The guidelines were all useful. However, they did not specifically address how physical distancing could best be implemented in a school setting while still securing children's need for care and to a certain extent, closer physical contact in the educational setting. Our guidelines also followed the main principles enforcing (i) self-isolation of sick children/ staff, (ii) hygiene measures and (iii) physical distancing measures. In addition, schools were required to establish procedures for students or staff who develop symptoms at school. Measures for enforced hand hygiene, respiratory hygiene, cleaning and disinfection will not be further discussed here. For details, see the Supplementary Material. 
Organisation of cohorts for physical distancing in primary schools during COVID-19 pandemic, Norway, 2020

\begin{tabular}{|c|c|}
\hline Grade & tion \\
\hline 1 to 4 (6-10 years) & $\begin{array}{l}\text { - As a general rule, one staff member should accompany the cohort } \\
\text { - The cohorts should minimise changing classrooms } \\
\text { - Within a cohort, pupils and staff can socialise and play together } \\
\text { - Separate desks } 1 \mathrm{~m} \text { apart recommended } \\
\text { - Cohorts should also be maintained in after-school programmes } \\
\text { - Cohorts } 1 \text { and } 2 \text { can work together for practical reasons during the day, preferably outdoors } \\
\text { - Staff from cohort } 1 \text { can provide relief in cohort } 2 \text {, and vice versa } \\
\text { - Cohorts } 3 \text { and } 4 \text {, and so on, should be organised in a similar way } \\
\text { - Cohorts } 1 \text { and } 2 \text { should generally not mix with cohorts } 3 \text { and } 4 \text {, and so on } \\
\text { - Cohorts that are not working together have separate areas or different time points for outdoor activities } \\
\text { - Cohorts that are not working together can mind each other and be in the same area for short periods of time (up to } \\
15 \text { min) } \\
\text { - Cohorts that are not working together can remain in the same room, provided that a distance of at least } 2 \mathrm{~m} \text { can } \\
\text { be maintained between the cohorts over a long period of time } \\
\text { - The composition of cohorts can be altered weekly after a weekend }\end{array}$ \\
\hline 5 to 7 (11-13 years) & $\begin{array}{l}\text { The recommendations given above apply, in addition to the following: } \\
\text { - Teachers can teach in different classes, but cohorts should remain in the same classroom } \\
\text { - Cohorts should move between classrooms as little as possible } \\
\text { - Pupils and staff within a cohort must strive to stay } 1 \mathrm{~m} \text { apart wherever possible } \\
\text { - Consider in-school teaching combined with digital education at home }\end{array}$ \\
\hline
\end{tabular}

We recommended establishing smaller, fixed groups of children and employees, in this setting called 'cohorts' as the key physical distancing measure. Reduced contact with others will limit the risk of transmission from presymptomatic and asymptomatic individuals. Establishment of cohorts takes into account that adhering to physical distancing measures is difficult for children and that physical contact is important for children's development and wellbeing. The cohort strategy ensures physical distancing between cohorts while allowing children's need for care. Within cohorts, the reduced number of children compared with ordinary classes provides more space and limits the number of contacts. Normally, one cohort is present in the classroom at the time.

The cohort strategy additionally enables rapid and easy contact tracing, and reduces the need for home quarantine. The identification of contacts between pupils is of high importance for appropriate screening and implementation of preventive measures for affected families and society [19]. With good management, a positive case will only affect the cohort and not the entire school, thereby preventing full school closure.

Cohort size was based on children's age and the need for care, as well as national regulations for teacher-pupil ratios; up to 15 pupils per teacher in grades 1 to 4 and 20 pupils per teacher in grades 5 to 7 . As older pupils can better comply by infection prevention measures, we suggested that groups of older pupils may be somewhat larger. The organisation of cohorts is described in Table 1.

In addition, we recommended to promote outdoor teaching, and to use larger rooms and facilities when possible. We also recommended that areas and situations with potential for crowding receive special attention regarding the possible need for additional measures to maintain distance. School assemblies, sports games and other gatherings were not advised. Other possibilities for reducing the number of pupils present were staggering the beginning and end of the school day or attendance on different days.

To support school administrators in implementing routines for IPC, we developed a checklist tool for school owners and staff (Table 2, Supplementary Material).

\section{Recommendations for children and staff at risk for severe COVID-19}

Publications on the COVID-19 pandemic report that most children develop mild disease, even those with severe underlying conditions [20-22]. The typical comorbidities 
TABLE 2

Checklist for school administrators to ensure infection prevention and control in primary schools during COVID-19 pandemic, Norway, 2020

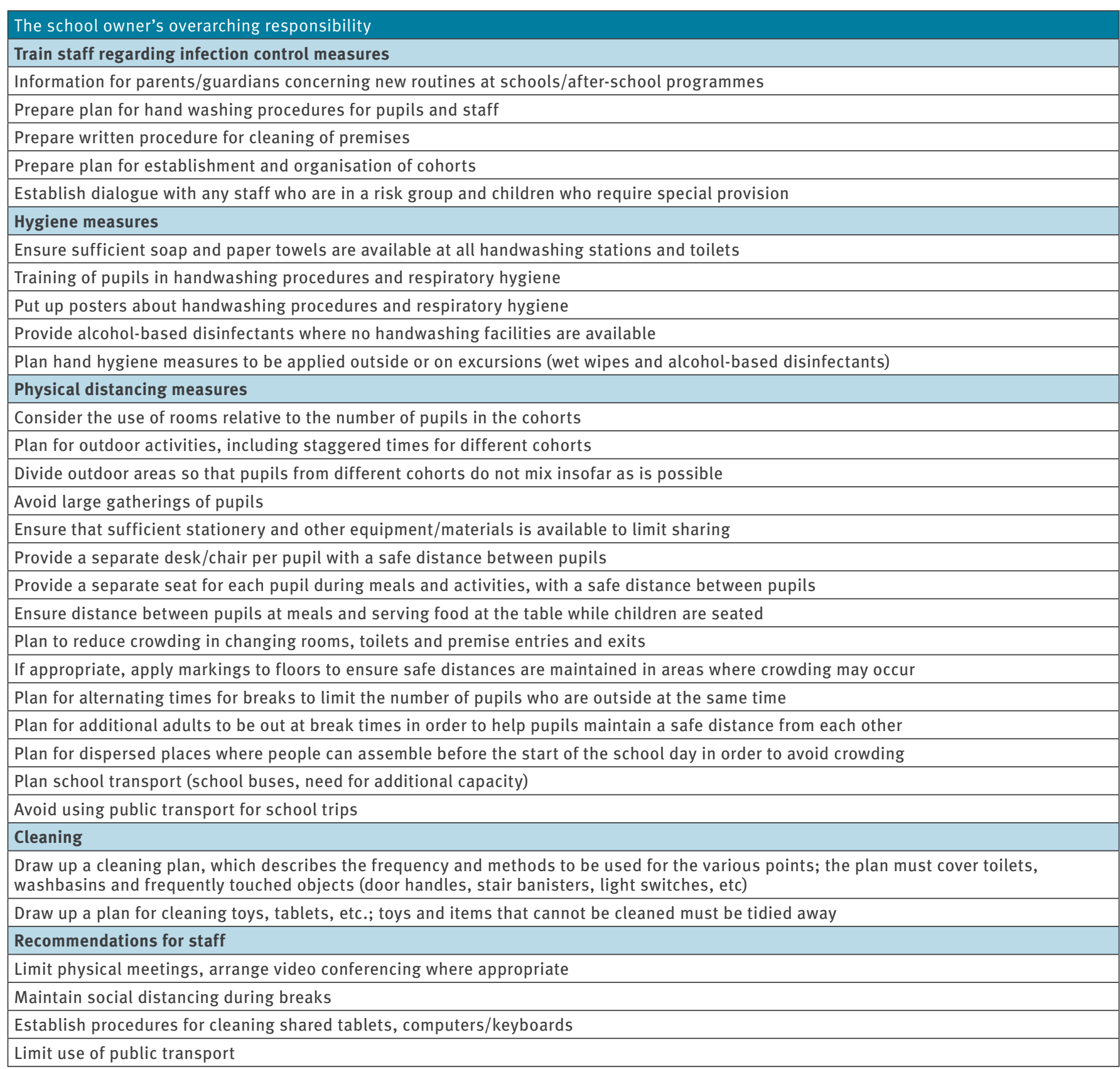

associated with severe COVID-19 in adults, particularly diabetes mellitus and hypertension, are associated with increasing age and are not observed in children [23]. The Norwegian Government requested guidelines for school attendance for children with chronic, severe underlying conditions before reopening schools. For this, the NIPH collaborated with the Norwegian Paediatric Association (NPA). A short background document was prepared, and an inquiry conducted between 8 and 13 April to all Paediatric Department Heads at hospitals and NPA-subspecialist committees. Paediatric conditions were evaluated in terms of risk of severe COVID-19 vs depriving children of education and social development. There was a paucity of experience and peer-reviewed publications on this topic from other countries. However, based on available evidence and expert opinion, NIPH and NPA suggested that most children can and should attend school, and that very few conditions justified preventative homeschooling. The NPA published the list of these conditions on their website [24] (Table 3, Supplementary Material).

School staff with high risk for severe COVID-19 also needed recommendations for when preventive selfisolation was indicated. Knowledge on risk factors was assessed in a rapid literature review by the NIPH [25]. Advanced age (> 65 years) was identified as the main risk factor, especially in combination with comorbidities, with the risk increasing with age. Diabetes mellitus and cardiovascular disease were also considered 


\section{TABLE 3}

List of common paediatric conditions where school attendance is encouraged (left column) and severe conditions where preventative homeschooling can be considered (right column) during COVID-19 pandemic, Norway, 2020

\begin{tabular}{|c|c|}
\hline Paediatric conditions where school attendance is encouraged & $\begin{array}{l}\text { Paediatric conditions where preventative homeschooling can be } \\
\text { considered }^{\mathrm{a}}\end{array}$ \\
\hline $\begin{array}{l}\text { - Diabetes mellitus } \\
\text { - Non-severe asthma } \\
\text { - Allergic conditions } \\
\text { - Epilepsy } \\
\text { - Cardiac conditions without heart failure } \\
\text { - Autoimmune conditions in a stable phase } \\
\text { - Solid organ transplant patients in a stable phase } \\
\text { - Children with Down syndrome }\end{array}$ & $\begin{array}{l}\text { - First months following solid organ transplantation } \\
\text { - First } 12 \text { months after stem cell transplantation } \\
\text { - Cancer patients during active chemotherapy } \\
\text { - Severe cardiac conditions with pulmonary hypertension, heart failure } \\
\text { or Fontan circulation } \\
\text { - Severe lung diseases and/or reduced lung capacity including need for } \\
\text { respiratory support } \\
\text { - Severe primary immunodeficiency } \\
\text { - Autoimmune disease requiring considerable immunosuppression or in } \\
\text { unstable phase } \\
\text { - Severe liver failure or renal failure } \\
\text { - Other rare conditions may also be considered }\end{array}$ \\
\hline
\end{tabular}

a These conditions may require homeschooling in certain periods or on occasion regardless of the COVID-19 pandemic.

to possibly represent a risk factor in adults $<65$ years. The NIPH recommended that individuals above the age of 65 years may continue preventative self-isolation, while other adults needed to consult their physician to assess individual risk. Employees at risk can still contribute to school education by working from home if possible.

\section{Discussion}

Education is one of the strongest predictors of a population's health and prosperity, and the impact of long-term school closures has not been evaluated [5]. Children have a right to attend school, which is crucial to their social, physical and psychological wellbeing [12].

The evidence for the effect of school closures on the reduction of COVID-19 disease burden is limited [5], while the negative consequences of school closures include the real risks of deepening social, economic and health inequities [26]. The government therefore decided to reopen schools after 6 weeks of closure. Our guidelines aimed to facilitate the process by providing practical support for schools and information to the public. There was a clear need to evaluate the potential risk for children with severe underlying conditions to ensure safe return to school, and communicate the conclusions to the public. We believe our guidelines may be of value for other countries that plan to reopen schools in the near future.

There was substantial concern about reopening schools among the population, and also among teachers and parents. Based on feedback from teachers' unions and media reports, the guidelines were perceived as reassuring, providing a manageable framework for safe reopening.
There is an urgent need to evaluate the effect of school closures on disease transmission vs the negative effects on children in the context of the COVID-19 pandemic. This is of paramount importance for possible future surges of COVID-19 as well as for future epidemics. In order to evaluate the effects of school opening on SARS-CoV-2 transmission, pupils and teachers will be prioritised for testing as part of the national surveillance strategy. In addition, a study is planned to examine the transmission of SARS-CoV-2 between children in daycare and primary school settings. This will allow us to better evaluate the effect of implementing IPC when reopening schools.

\section{Acknowledgements}

We would like to acknowledge our colleagues at NIPH and NDET for valuable discussions and input, and especially Trude Lyngstad for providing surveillance data and help with the figure. We also thank the Norwegian Paediatric Association for excellent cooperation and EUPHEM coordinator Loredana Ingrosso for reviewing the manuscript.

Conflict of interest

None declared.

Authors' contributions

All authors were involved in developing the national guidelines. TBJ, MGI, EA and SJ together drafted the manuscript. MGI and CK were responsible for risk assessment for children and severe COVID-19. HN and BBD were responsible for adaptation of IPC measures in the educational setting. ASB represents the outbreak response management group at NIPH, and coordinated communication with relevant government bodies. All authors provided critical feedback and helped shape the manuscript. 


\section{References}

1. United Nations Educational, Scientific and Cultura Organization (UNESCO). COVID-19 school closures around the world will hit girls hardest. Paris: UNESCO; 2020. Available from: https://en.unesco.org/news/ covid-19-school-closures-around-world-will-hit-girls-hardest

2. Norwegian Institute of Public Health (NIPH). COVID-19epidemien: Risiko, progonose og respons i Norge etter uke 12. [COVID-19 epidemic. Risk, prognosis and response in Norway following week 12]. Oslo: NIPH; 24 Mar 2020. Norwegian. Available from: https://www.fhi.no/contentassets/ c9e459cd7cc24991810aod28d7803bdo/covid-19-epidemienrisiko-prognose-og-respons-i-norge-etter-uke-12.--medvedlegg.-24.mars-2020.pdf/

3. Google. COVID-19 Community Mobility Reports. 2020. [Accessed 12 May 2020]. Available from: https://www.google. com/covid19/mobility/

4. Norwegian Institute of Public Health (NIPH). COVID-19epidemien: Kunnskap, situasjon, prognose, risiko og respons i Norge etter uke 14. [COVID-19 epidemic. Knowledge, situation, prognosis, risk and response in Norway following week 14]. Oslo: NIPH; 5 May 2020. Available from: https://www.fhi.no/ contentassets/c9e459cd7cc24991810aod28d7803bdo/notatom-risiko-og-respons-2020-04-05.pdf

5. Viner RM, Russell SJ, Croker H, Packer J, Ward J, Stansfield $C$, et al. School closure and management practices during coronavirus outbreaks including COVID-19: a rapid systematic review. Lancet Child Adolesc Health. 2020;4(5):397-404. https://doi.org/10.1016/S2352-4642(20)30095-X PMID: 32272089

6. Zhao S, Lin Q, Ran J, Musa SS, Yang G, Wang W, et al. Preliminary estimation of the basic reproduction number of novel coronavirus (2019-nCoV) in China, from 2019 to 2020: A data-driven analysis in the early phase of the outbreak. Int J Infect Dis. 2020;92:214-7. https://doi.org/10.1016/j. ijid.2020.01.050 PMID: 32007643

7. Liu Y, Gayle AA, Wilder-Smith A, Rocklöv J. The reproductive number of COVID-19 is higher compared to SARS coronavirus. J Travel Med. 2020;27(2):taaa021. https://doi.org/10.1093/jtm/ taaa021 PMID: 32052846

8. Lai CC, Shih TP, Ko WC, Tang HJ, Hsueh PR. Severe acute respiratory syndrome coronavirus 2 (SARS-CoV-2) and coronavirus disease-2019 (COVID-19): The epidemic and the challenges. Int J Antimicrob Agents. 2020;55(3):105924. https://doi.org/10.1016/j.ijantimicag.2020.105924 PMID: 32081636

9. Gudbjartsson DF, Helgason A, Jonsson H, Magnusson OT, Melsted P, Norddahl GL, et al. Spread of SARS-CoV-2 in the Icelandic Population. N Engl J Med. 2020;NEJMoa2006100. https://doi.org/10.1056/NEJMoa2006100 PMID: 32289214

10. Brurberg $\mathrm{K}$. The role of children in the transmission of SARSCoV-2 (COVID-19), 1st update - a rapid review. Oslo: Norwegian Institute of Public Health; 30 Apr 2020. Available from: https:// www.fhi.no/en/publ/2020/The-role-of-children-in-thetransmission-of-SARS-CoV-2-COVID-19-1st-update/

11. Wu Z, McGoogan JM. Characteristics of and Important Lessons From the Coronavirus Disease 2019 (COVID-19) Outbreak in China: Summary of a Report of 72314 Cases From the Chinese Center for Disease Control and Prevention. JAMA. 2020;323(13):1239-42. https://doi.org/10.1001/ jama.2020.2648 PMID: 32091533

12. United Nations (UN). Convention on the Rights of the Child, Article 28. UN: 2 Sep 1990. Available from: https://www.ohchr. org/en/professionalinterest/pages/crc.aspx

13. Lovdata. Regulations relating to infection control measures etc. in connection with the coronavirus outbreak (COVID-19 Regulations), Section $12 \mathrm{~A}$. [Forskrift om smitteverntiltak mv. ved koronautbruddet (covid-19forskriften), § 12a. Åpen virksomhet ved barnehager, skoler og utdanningsinstitusjoner]. 8 April 2020. [Accessed 12 May 2020]. Norwegian. Available from: https://lovdata.no/ dokument/SF/forskrift/2020-03-27-470

14. International Federation of the Red Cross (IFRC), World Health Organization (WHO), United Nations Children's Fund (UNICEF). Key messages and actions for COVID-19 prevention and control in schools. IFRC/WHO/UNICEF; 10 Mar 2020. Available from: https://www.who.int/docs/default-source/coronaviruse/keymessages-and-actions-for-covid-19-prevention-and-control-inschools-march-2020.pdf?sfvrsn=baf81d52_4

15. Public Health Agency of Canada (PHAC). Public health guidance for schools (K-12) and childcare programs (COVID-19). Ottawa: PHAC; 2020. [Accessed 6 Apr 2020]. Available from: https:// www.canada.ca/en/public-health/services/diseases/2019novel-coronavirus-infection/health-professionals/guidanceschools-childcare-programs.html
16. Danish Health Authority. Materialer til genåbning af skoler og fritidsordninger. [Materials for reopening schools and after school programs]. Copenhagen: Danish Health Authority; 2020. [Accessed 6 Apr 2020]. Danish. Available from: https://www. sst.dk/da/udgivelser/2020/genaabning-af-skoler

17. Department for Education, Public Health England (PHE). Coronavirus (COVID-19): guidance for educational settings. Gov.uk; 2020. [Accessed 6 Apr 2020]. Available from: https://www.gov.uk/government/publications/ guidance-to-educational-settings-about-covid-19/ guidance-to-educational-settings-about-covid-19

18. United States Centres for Disease Control and Prevention (CDC). Coronavirus Disease 2019 (COVID-19). Considerations for Schools. Atlanta: CDC; 2020. [Accessed 6 Apr 2020]. Available from: https://www.cdc.gov/coronavirus/2019-ncov/community/ schools-childcare/schools.html

19. Vanhems P. SARS-CoV2 infection and primary school closure. Euro Surveill. 2020;25(15):2000617. https://doi. org/10.2807/1560-7917.ES.2020.25.15.2000617 PMID: 32317053

20. Bialek S, Gierke R, Hughes M, McNamara LA, Pilishvili T, Skoff T, CDC COVID-19 Response Team. Coronavirus Disease 2019 in Children - United States, February 12-April 2, 2020. MMWR Morb Mortal Wkly Rep. 2020;69(14):422-6. https://doi. org/10.15585/mmwr.mm6914e4 PMID: 32271728

21. Rasmussen SA, Thompson LA. Coronavirus Disease 2019 and Children: What Pediatric Health Care Clinicians Need to Know. JAMA Pediatr. 2020. https://doi.org/10.1001/ jamapediatrics.2020.1224 PMID: 32242896

22. Garazzino S, Montagnani C, Donà D, Meini A, Felici E, Vergine $\mathrm{G}$, et al. Multicentre Italian study of SARS-CoV-2 infection in children and adolescents, preliminary data as at 10 April 2020. Euro Surveill. 2020;25(18):2000600. https://doi. org/10.2807/1560-7917.ES.2020.25.18.2000600 PMID: 32400362

23. Zhou F, Yu T, Du R, Fan G, Liu Y, Liu Z, et al. Clinical course and risk factors for mortality of adult inpatients with COVID-19 in Wuhan, China: a retrospective cohort study. Lancet. 2020;395(10229):1054-62. https://doi.org/10.1016/S01406736(20)30566-3 PMID: 32171076

24. Greve-Isdahl M, Klingenberg K. Vurdering av barn med kronisk, alvorlig sykdom og risiko for alvorlig forløp av covid-19 i forbindelse med gjenåpning av barnehager og skoler. [Evaluation of children with chronic diseases and risk of severe COVID-19 when re-opening daycare and schools]. Oslo: Norwegian Institute for Public Health, Norwegian Paediatric Association; 15 April 2020. [Accessed 12 May 2020]. Norwegian. Available from: https://www.legeforeningen. no/contentassets/14b5140eb743406aa07b3e3bo912 fe70/20200423_nbf_skoleapning-og-vurdering-av-barn-medmulig-risiko.pdf.

25. Brurberg KG, Fretheim A. COVID-19: The relationship between age, comorbidity and disease severity- a rapid review, 1st update. Oslo: Norwegian Institute of Public Health; Apr 2020. Available from: https://www.fhi.no/en/publ/2020/COVID19-The-relationship-between-age-comorbidity-and-diseaseseverity-1st-update/

26. Esposito S, Principi N. School Closure During the Coronavirus Disease 2019 (COVID-19) Pandemic: An Effective Intervention at the Global Level? JAMA Pediatr. 2020. https://doi.org/10.1001/ jamapediatrics.2020.1892 PMID: 32401277

\section{License, supplementary material and copyright}

This is an open-access article distributed under the terms of the Creative Commons Attribution (CC BY 4.0) Licence. You may share and adapt the material, but must give appropriate credit to the source, provide a link to the licence and indicate if changes were made.

Any supplementary material referenced in the article can be found in the online version.

This article is copyright of the authors or their affiliated institutions, 2020. 